Research Paper

\title{
Antimicrobial activity of allylic thiocyanates derived from the Morita-Baylis-Hillman reaction
}

\author{
Marcus Mandolesi Sá ${ }^{1}$, Misael Ferreira ${ }^{1}$, Emerson Silva Lima ${ }^{2}$, Ivanildes dos Santos ${ }^{3}$, \\ Patrícia Puccinelli Orlandi ${ }^{3}$, Luciano Fernandes ${ }^{4}$ \\ ${ }^{1}$ Departamento de Química, Universidade Federal de Santa Catarina, Florianópolis, SC, Brazil. \\ ${ }^{2}$ Faculdade de Ciências Farmacêuticas, Universidade Federal do Amazonas, Manaus, AM, Brazil. \\ ${ }^{3}$ Coordenação de Biodiversidade em Saúde, Centro de Pesquisa Leônidas e Maria Deane, \\ Fundação Oswaldo Cruz, Manaus, AM, Brazil. \\ ${ }^{4}$ Departamento de Engenharia Química, Universidade Tecnológica Federal do Paraná, \\ Ponta Grossa, PR, Brazil.
}

Submitted: December 19, 2012; Approved: December 13, 2013.

\begin{abstract}
Bacterial resistance to commonly used antibiotics has been recognized as a significant global health issue. In this study, we carried out the screening of a family of allylic thiocyanates for their action against a diversity of bacteria and fungi with a view to developing new antimicrobial agents. Allylic thiocyanates bearing halogenated aryl groups, which were readily obtained in two steps from the Morita-Baylis-Hillman adducts, showed moderate-to-high activity against selective pathogens, including a methicillin-resistant $S$. aureus (MRSA) strain. In particular cases, methyl (Z)-3-(2,4dichlorophenyl)-2-(thiocyanomethyl)-2-propenoate exhibited antimicrobial activity comparable to the reference antibiotic Imipenem.
\end{abstract}

Key words: antimicrobial, allylic thiocyanate, Morita-Baylis-Hillman reaction, MRSA.

\section{Introduction}

Despite the great efforts that have been put forth to discover novel types of antimicrobial agents, the battle against pathogenic microorganisms is far from being settled owing to the emergence of drug-resistant strains (Foss et al., 2011; Kohanski et al., 2010; Lee and Collins, 2012; Silveira et al., 2006; Walsh, 2000). Bacterial resistance to commonly used antibiotics is recognized as a significant global health issue, being related to a considerable number of cases where the conventional chemotherapeutic treatment of microbial infections has failed. Consequently, the search for novel classes of molecules associated with higher potency, an expanded spectrum of activity and an improved safety profile is urgently required (Diekema and Jones, 2001; Reck et al., 2005).

Many organic compounds containing the S-C-N framework are related to potent biological activity (Allan et al., 1997; Liu et al., 2008; Regan et al., 1967). In particular, the antifungal and antibacterial profiles of thioureas, isothioureas and thiosemicarbazones have been well documented (Chimenti et al., 2011; Iwai et al., 2007; Pavan et al., 2010; Saeed et al., 2010; Umamatheswari et al., 2011). However, the biological activity related to the thiocyanate functionality is much less frequently reported (Capon et al., 2004; Elhalem et al., 2002; Liñares et al., 2007).

In the course of our research interest (Meier et al., 2012; Sá, 2003; Sá et al., 2007) in the chemistry of MoritaBaylis-Hillman (MBH) adducts (Basavaiah et al., 2010; Basavaiah and Veeraraghavaiah, 2012; Singh and Batra, 2008 ) and the antimicrobial activity of synthetic derivatives (Silveira et al., 2012), we have been able to readily install the S-C-N framework through chemical synthesis in aqueous medium under mild conditions to give the corresponding allylic isothiouronium salts or thiocyanates in excellent yields. Herein, we present our results for the screening of a family of allylic thiocyanates against bacteria and 
fungi strains with a view to developing novel antibiotic agents.

\section{Materials and Methods}

\section{General experimental procedures}

Analytical reagent grade chemicals and solvents were obtained commercially and used without further purification. Melting points were determined using a Microquímica MQPF301 hot plate apparatus and are uncorrected. Infrared spectra were acquired with a Perkin-Elmer FT-IR 1600 spectrometer (range 4000-400 $\mathrm{cm}^{-1}$ ) using $\mathrm{KBr}$ for solids and film for liquid samples. Elemental analyses were conducted on a CHNS Carlo Erba EA-1110 microanalyzer and the analytical results were within $\pm 0.4 \%$ of the theoretical values for all compounds. ${ }^{1} \mathrm{H}$ NMR spectra were recorded at 400 $\mathrm{MHz}$ and splitting patterns were designated as s (singlet), $\mathrm{d}$ (doublet), $\mathrm{t}$ (triplet), $\mathrm{m}$ (multiplet). Coupling constants $(J)$ were determined in Hertz (Hz). ${ }^{13} \mathrm{C}$ NMR spectra (fully decoupled) were recorded at $100 \mathrm{MHz}$. Chemical shifts were recorded in parts per million (ppm, $\delta$ ) relative to $\mathrm{CDCl}_{3}$ (at $7.26 \mathrm{ppm}$ for ${ }^{1} \mathrm{H} \mathrm{NMR}$, and at $77.2 \mathrm{ppm}$ for ${ }^{13} \mathrm{C} \mathrm{NMR}$ ) as the internal standard. Column chromatography was performed using silica gel (70-230 mesh) and hexane/ethyl acetate as the eluent. TLC analysis was performed on silica gel plates. Allylic bromides 1a-m and thiocyanates 2a-m (Figure 1) were synthesized according to the described methods (Ferreira et al., 2009; Sá et al., 2006, 2008; Silveira et al., 2012). Purification of $2 \mathrm{a}-\mathrm{m}$ in a short plug of silica gel furnished pure products as crystalline solids in all but two cases ( $2 \mathrm{f}$ and $2 \mathrm{~h}$ ), where the product remained oily. The physical and spectral data for allylic bromides 1a-d,f,g,i,k-m (Ferreira et al., 2009; Sá et al., 2006) and thiocyanates 2a-m (Sá et al., 2008; Silveira et al., 2012) are in accordance with spectral data in literature. Data for novel bromides 1e, $1 \mathrm{~h}$, and $1 \mathrm{j}$ :

Methyl (Z)-2-(bromomethyl)-3-(2-nitrophenyl)-2propenoate (1e). Yield 83\%; yellow solid, mp 63.0-64.0 ${ }^{\circ} \mathrm{C}$. IR (KBr) $v_{\max } / \mathrm{cm}^{-1} 3042,2948,1713,1518$, 1435, 1338, 1273, 1201, 1152. ${ }^{1} \mathrm{H}$ NMR (400 MHz, $\left.\mathrm{CDCl}_{3}\right): \delta 3.88(\mathrm{~s}, 3 \mathrm{H}), 4.12(\mathrm{~s}, 2 \mathrm{H}), 7.60(\mathrm{t}, J 8.0 \mathrm{~Hz}, 1 \mathrm{H})$, 7.69-7.78 (m, 2H), $8.04(\mathrm{~s}, 1 \mathrm{H}), 8.20$ (d, J 8.0 Hz, 1H). ${ }^{13} \mathrm{C}$ NMR (100 MHz, $\left.\mathrm{CDCl}_{3}\right)$ : $\delta$ 25.8, 52.8, 125.4, 130.08, $130.13,130.2,130.5,134.2,139.8,147.4,165.8$.

Methyl (Z)-2-(bromomethyl)-3-(4-fluorophenyl)-2propenoate (1h). Yield 91\%; clear yellow oil. IR (neat):

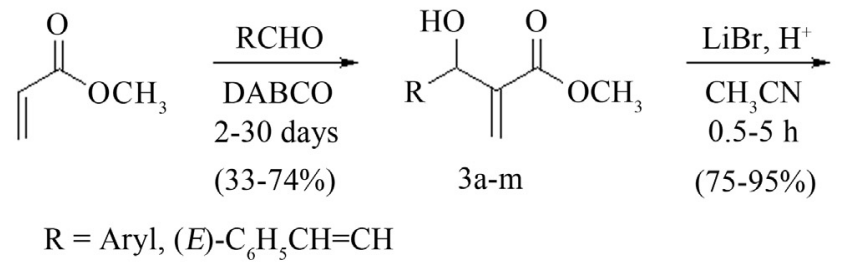

$v_{\max } / \mathrm{cm}^{-1} 3071,2950,1717,1629,1599,1509,1437,1271$, 1230, 1154. ${ }^{1} \mathrm{H}$ NMR (400 MHz, $\left.\mathrm{CDCl}_{3}\right): \delta 3.84(\mathrm{~s}, 3 \mathrm{H})$, 4.33 (s, 2H), 7.12 (t, J 8.5 Hz, 2H), 7.53-7.56 (m, 2H), 7.74 (s, 1H). $\left.{ }^{13} \mathrm{C} \mathrm{NMR} \mathrm{(100} \mathrm{MHz,} \mathrm{CDCl}_{3}\right): \delta 26.6,52.6,116.1$ (d, $J 22.0 \mathrm{~Hz}), 128.4,130.4$ (d, $J 3.6 \mathrm{~Hz}), 131.9$ (d, $J 8.1$ $\mathrm{Hz}), 141.8,163.2$ (d, J 250.6 Hz), 166.5.

Methyl (Z)-2-(bromomethyl)-3-(2-bromophenyl)-2propenoate (1j). Yield 78\%; white solid, mp 83.5-84.5 ${ }^{\circ} \mathrm{C}$. IR $(\mathrm{KBr}) v_{\max } / \mathrm{cm}^{-1} 3083,3011,2956,1709,1625,1582$, 1448, 1357, 1285, 1215, 1156. ${ }^{1} \mathrm{H}$ NMR (400 MHz, $\left.\mathrm{CDCl}_{3}\right): \delta 3.90(\mathrm{~s}, 3 \mathrm{H}), 4.24(\mathrm{~s}, 2 \mathrm{H}), 7.26(\mathrm{t}, J 7.8 \mathrm{~Hz}, 1 \mathrm{H})$, 7.42 (t, J $7.8 \mathrm{~Hz}, 1 \mathrm{H}), 7.63$ (d, J $7.8 \mathrm{~Hz}, 1 \mathrm{H}), 7.68$ (d, J 7.8 $\mathrm{Hz}, 1 \mathrm{H}), 7.84(\mathrm{~s}, 1 \mathrm{H}) .{ }^{13} \mathrm{C} \mathrm{NMR}\left(100 \mathrm{MHz}, \mathrm{CDCl}_{3}\right): \delta 26.3$, $52.7,124.5,127.7,129.7,130.3,130.8,133.1,134.8$, $141.8,166.1$.

\section{Microorganisms}

Screening of the in vitro antimicrobial activity of allylic thiocyanates 2 against a series of standard strains was carried out (Table 1), including Gram-positive (Bacillus cereus ATCC 9634, methicillin-sensitive Staphylococcus aureus ATCC 25923, methicillin-resistant Staphylococcus aureus ATCC 33591) and Gram-negative (Pseudomonas aeruginosa PA01) (Stover et al., 2000) bacteria. Strains of C. albicans (ATCC 90028) were kindly provided by the University of São Paulo (USP, Brazil) and Candida tropicalis were isolated from the oral cavity of patients with removable dentures (Freire et al., 2010).

\section{Antibacterial profile of thiocyanates 2 by the agar diffusion test}

This section follows the instructions from Clinical and Laboratory Standards Institute (CLSI), with modifications (Watts et al., 2008). The bacterial strains grown on nutrient agar (Himedia, Mumbai, India) at $37{ }^{\circ} \mathrm{C}$ for $24 \mathrm{~h}$ were suspended in a saline solution $(0.85 \% \mathrm{NaCl})$ and adjusted to a turbidity equivalent to the $0.5 \mathrm{McF}$ arland standard $\left(10^{8} \mathrm{CFU} \mathrm{mL}^{-1}\right)$. The inoculum was applied $(1: 10 \mathrm{v} / \mathrm{v})$ to a Müeler-Hinton agar (Himedia, Mumbai, India) into Petri dishes (90 mm diameter), which were previously prepared with a lower layer of agar. Wells (6 mm diameter) were punched in the inoculated Müeler-Hinton agar and filled with $100 \mu \mathrm{L}$ of $1 \mathrm{mg} \mathrm{mL}^{-1}$ solution of the test compounds. The dissolution of the test compounds in water was obtained by adding $1 \%(\mathrm{v} / \mathrm{v})$ DMSO, which was used as
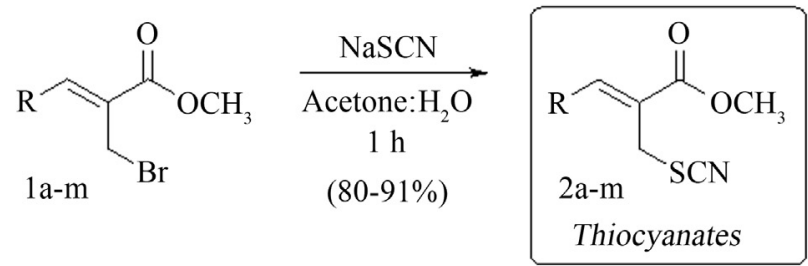

Figure 1 - Three-step preparation of allylic thiocyanates 2a-m (chemical yields are in brackets). 
negative control that did not affect the growth of microorganisms, according to the control experiments.

Plates were incubated at $37^{\circ} \mathrm{C}$ for $24 \mathrm{~h}$. The experiments were conducted in triplicate. Imipenem was used as a positive control because we found that this drug had an excellent in vitro activity against the MRSA strain tested. In order to visualize the activity, $8 \mu \mathrm{L}$ of a triphenyltetrazolium chloride solution $(0.1 \%)$, together with bacteriological agar $(1 \%)$, were added and the plates were incubated again at $37^{\circ} \mathrm{C}$ for $4 \mathrm{~h}$. Antibacterial activity was evaluated by measuring the diameter of the inhibition zone in millimeters (Anesini and Perez, 1993). The activity of each substance was compared with the positive control. The substance was classified as no inhibitor (diameter $<25 \%$ of the positive control), weak inhibitor (diameter between $25 \%$ and $50 \%$ ), moderate inhibitor (diameter between $50 \%$ and $75 \%$ ), good inhibitor (diameter between $75 \%$ and $99 \%$ ) or excellent inhibitor (diameter equal or higher than 100\%).

\section{Determination of minimal inhibitory concentration (MIC)}

The test used for determining the MIC for bacterial strains was the microdilution method (Mann and Markham, 1998; Watts et al., 2008) with modifications of the original procedure, including the addition of the colorimetric growth indicator resazurin, which is reduced when viable bacterial cells are present, as previously described (Cursino et al., 2011). Serial three-fold dilutions starting at $50 \mu \mathrm{M}$ of each test compound were prepared by vortexing in DMSO at room temperature. The Luria-Bertani broth (LB - Himedia, Mumbai, India) was inoculated with the test bacteria to yield a final cell density around $1 \log$ cycle lower than the cell density required to reduce resazurin (usually $2.5 \times 10^{5} \mathrm{cell} \mathrm{mL}^{-1}$ ). The inoculum density was confirmed by plate counts. A sterile 96-well microtiter plate was set up with each of the test bacteria as follows: $100 \mu \mathrm{L}$ inoculum $+100 \mu \mathrm{L}$ test compound $(0.1-50 \mu \mathrm{M}) ; 100 \mu \mathrm{L}$ inoculum $+100 \mu \mathrm{L}$ DMSO (growth positive control); and sterile medium $+100 \mu \mathrm{L}$ DMSO (negative control). The well contents were thoroughly mixed. Two trays were prepared for each organism and incubated at $37{ }^{\circ} \mathrm{C}$ for $3 \mathrm{~h}$. After incubation, $30 \mu \mathrm{L}$ of resazurin solution $\left(6 \mu \mathrm{g} \mathrm{mL}^{-1}\right)$ was added to all wells. After a second incubation for $4 \mathrm{~h}$ at $37^{\circ} \mathrm{C}$, the wells were visually analyzed for color change. Inhibition was considered when the bacterial count did not increase after the incubation time and resazurin was not reduced to pink color; the highest dilution which remains blue was considered the MIC.

\section{In vitro antifungal activity}

The in vitro antifungal activity of thiocyanates 2 was assessed by either agar diffusion test or broth microdilution in accordance with the CLSI guidelines (Pfaller et al., 2002). The test compounds 2 were suspended in DMSO and diluted in the RPMI 1640 medium with L-glutamine
(Life Technologies, Grand Island, NY), which was previously buffered to $\mathrm{pH} 7.0$ with $0.165 \mathrm{M}$ MOPS and supplemented with $18 \mathrm{~g} \mathrm{~L}^{-1}$ of glucose. To activate the strains, they were subcultured on Sabouraud's dextrose agar for $24 \mathrm{~h}$ at $35^{\circ} \mathrm{C}$. A suspension of yeast cells with a turbidity of 0.5 , according to the McFarland standard, was prepared in distilled water, adjusted in a Neubauer chamber (Brand, Wertheim, Germany) and diluted to the final inoculum concentration in the range of $0.5 \times 10^{3}$ to $2.5 \times 10^{3}$ $\mathrm{CFU} \mathrm{mL}{ }^{-1}$. All assays were performed in triplicate. The microtiter plates containing the test compounds and the inoculum were incubated at $35{ }^{\circ} \mathrm{C}$ for $24 \mathrm{~h}$. Minimum inhibitory concentration (MIC) values were assessed visually by two separate investigators and defined as the lowest concentration that resulted in no growth. Itraconazole was used in the experiments as the antifungal standard.

\section{Results and Discussion}

A diversity of $S$-substituted allylic derivatives has been successfully prepared as reported in previous publications (Sá et al., 2008, 2010; Silveira et al., 2012). Allylic bromides 1 are the precursors for thiocyanates 2, obtained in high yields through halide displacement by the thiocyanate anion ( $\left.\mathrm{NCS}^{-}\right)$in aqueous medium at room temperature (Figure 1). The key bromides 1 are readily prepared by treating $\alpha$-methylene- $\beta$-hydroxyesters 3 (MBH adducts) with $\mathrm{LiBr}$ in acidic medium at room temperature (Ferreira et al., 2009; Sá et al., 2006). This two-step transformation (MBH reaction followed by bromination) is routinely performed in multigram scale with an overall yield of $65-85 \%$ (13 examples) and thus offers a practical route to produce the starting material 1 .

Screening of the in vitro antimicrobial activity of allylic thiocyanates 2 against a series of standard strains was carried out (Table 1). Moderate antimicrobial activity was found for toluoyl- (2f), naphthyl- (2g), and fluorophenyl(2h) substituted allylic thiocyanates, while much more significant results were observed for the bromo and chloro analogues (2i-m). In particular, the three chloro-substituted thiocyanates screened $(2 \mathrm{k}-\mathrm{m})$ were highly active, with inhibition zones of the same magnitude or even greater than the positive control Imipenem (Table 1). It is also worth mentioning the higher potency associated with the 2,4-dichloro-substituted thiocyanate $2 \mathrm{~m}$ compared with both the 4- and 2-monosubstituted analogues $2 \mathrm{k}$ and 21 , which is indicative of a synergistic effect of the chloro substitution. Most importantly, a handful of compounds exhibited moderate-to-high activity against both methicillin-sensitive $S$. aureus (MSSA) and methicillin-resistant $S$. aureus (MRSA). Multidrug-resistant organisms pose important treatment challenges. Perhaps no organism has received more attention than MRSA (Kallen et al., 2010). Unfortunately, the growing incidence of MRSA has been met with insufficient efforts to combat this important public health 
Table 1 - In vitro antimicrobial activity of thiocyanates 2 against selected strains ${ }^{\mathrm{a}, \mathrm{b}}$.

\begin{tabular}{|c|c|c|c|c|c|c|}
\hline$\#$ & $\mathrm{R}$ & C. albicans & P. aeruginosa & B. cereus & MSSA & MRSA \\
\hline $2 \mathrm{a}$ & $\mathrm{C}_{6} \mathrm{H}_{5}$ & NT & NA & NA & NA & NA \\
\hline $2 b$ & 4- $\mathrm{CH}_{3} \mathrm{OC}_{6} \mathrm{H}_{4}$ & NT & NA & NA & NA & NA \\
\hline $2 \mathrm{c}$ & $3,4-\left(\mathrm{OCH}_{2} \mathrm{O}\right) \mathrm{C}_{6} \mathrm{H}_{3}$ & NT & NA & NA & NA & NA \\
\hline $2 \mathrm{~d}$ & (E) $-\mathrm{C}_{6} \mathrm{H}_{5} \mathrm{CH}=\mathrm{CH}$ & NT & NA & NA & NA & NA \\
\hline $2 \mathrm{e}$ & $2-\mathrm{NO}_{2} \mathrm{C}_{6} \mathrm{H}_{4}$ & NT & NA & NA & NA & NA \\
\hline $2 f$ & $4-\mathrm{CH}_{3} \mathrm{C}_{6} \mathrm{H}_{4}$ & NA & NT & $12 \pm 3$ & $12 \pm 2$ & NA \\
\hline $2 \mathrm{~g}$ & $2-\mathrm{C}_{10} \mathrm{H}_{7}$ & NA & NT & $13 \pm 1$ & $15 \pm 1$ & $15 \pm 1$ \\
\hline $2 \mathrm{~h}$ & 4- $\mathrm{FC}_{6} \mathrm{H}_{4}$ & $13 \pm 1$ & NT & $12 \pm 3$ & $15 \pm 2$ & NA \\
\hline $2 \mathrm{i}$ & $4-\mathrm{BrC}_{6} \mathrm{H}_{4}$ & $13 \pm 1$ & NT & $17 \pm 1$ & $18 \pm 2$ & $17 \pm 1$ \\
\hline $2 \mathrm{j}$ & $2-\mathrm{BrC}_{6} \mathrm{H}_{4}$ & $13 \pm 1$ & NT & NA & $21 \pm 1$ & $14 \pm 1$ \\
\hline $2 \mathrm{k}$ & 4- $\mathrm{ClC}_{6} \mathrm{H}_{4}$ & $22 \pm 2$ & NT & NA & $19 \pm 2$ & $15 \pm 1$ \\
\hline 21 & 2- $\mathrm{ClC}_{6} \mathrm{H}_{4}$ & NA & NA & $18 \pm 2$ & $21 \pm 2$ & NA \\
\hline \multirow[t]{3}{*}{$2 \mathrm{~m}$} & $2,4-\mathrm{Cl}_{2} \mathrm{C}_{6} \mathrm{H}_{3}$ & $19 \pm 2$ & NA & $19 \pm 1$ & $25 \pm 6$ & $19 \pm 1$ \\
\hline & Imipenem & NT & $30 \pm 1$ & $20 \pm 1$ & $21 \pm 3$ & $19 \pm 2$ \\
\hline & Itraconazole & $28 \pm 2$ & NT & NT & NT & NT \\
\hline
\end{tabular}

${ }^{a}$ Antimicrobial activity, expressed as inhibition zone diameter in millimeters $(\mathrm{mm})$, of chemical compounds against the pathological strains based on agar well diffusion assays at $1 \mathrm{mg} \mathrm{mL}^{-1}$. The experiment was carried out in triplicate and the average zone of inhibition was calculated.

${ }^{\mathrm{b}} \mathrm{NA}=$ Not active; $\mathrm{NT}=$ not tested.

issue. Therefore, the continued emergence of MRSA demands an urgent need to develop new, more effective antibiotics (Morell and Balkin, 2010).

Among the thiocyanates screened against MRSA, the dichloro-substituted analog $2 \mathrm{~m}$ was found to be the most active, with a remarkable potency that is comparable to Imipenem. Interesting, $P$. aeruginosa was the sole strain that was not sensitive to any of the thiocyanates 2 tested. This observation is suggestive of a selective action against Gram-positive rather than Gram-negative bacteria (Pieri et al., 2011).

Antifungal activity of thiocyanates $2 \mathrm{a}-\mathrm{m}$ was also studied for the first time, and the results are shown in Table 1. Most of the compounds were inactive against $C$. albicans, but the chloro derivatives $2 \mathrm{k}$ and $2 \mathrm{~m}$ exhibited a moderate-to-good action compared to Itraconazole as the positive reference.

MIC determination for the selected chloro derivatives $2 \mathrm{k}, 21$, and $2 \mathrm{~m}$ was carried out using a microdilution assay (Watts et al., 2008) modified with resazurin growth indicator that made easily to establish the size of inhibition zones. These compounds showed good-to-high potency (3-6 $\mu \mathrm{M})$ against both strains of $S$. aureus and the results are compiled in Table 2. As anticipated from the agar diffusion method in Table 1, chloro derivatives $2 \mathrm{k}$ and $2 \mathrm{~m}$ also presented good antifungal activity $(6-25 \mu \mathrm{M})$ against both Candida species under evaluation.
In the development of promising new antitubercular agents, we have recently reported that 4-chloro-substituted thiocyanate $2 \mathrm{k}$, as well as the two bromo-substituted analogues $2 \mathrm{i}$ and $2 \mathrm{j}$, were highly active against replicating and non-replicating forms of Mycobacterium tuberculosis (Mtb) $\mathrm{H}_{37} \mathrm{Rv}$, with relatively low toxicity toward VERO cells (Silveira et al., 2012). In the current screening for antimicrobial activity (Tables 1 and 2), these three compounds were also potent against some of the strains under study. On the other hand, the chloro-derivatives 21 and $2 \mathrm{~m}$, which were inactive against Mtb (MICs $>128 \mu \mathrm{M})$ (Silveira et al., 2012), were found to be potent inhibitors of MSSA and, in the case of $2 \mathrm{~m}$, of MRSA. Therefore, some of the thiocyanates 2 are more likely to be related to a broadspectrum of activity, including against $M t b$, Gram-positive bacteria and fungi $(2 \mathrm{i}, 2 \mathrm{j}$, and $2 \mathrm{k}$ ), while other analogues can be considered as powerful agents against a selective group of bacteria and fungi but not $M t b(21$ and $2 \mathrm{~m})$.

\section{Conclusions}

Allylic thiocyanates bearing halogenated aryl groups, in particular the dichloro-substituted analog $2 \mathrm{~m}$, were found to be active against a diversity of pathogen strains. Both MRSA and MSSA as well as the two Candida species were susceptible to some of the thiocyanates screened, but the $P$. aeruginosa strain tested was not. The analogues identified as the most active possess a bromoaryl or a chloroaryl group, and the presence of a second chlorine 
Table 2 - Selected antimicrobial activity of thiocyanates 2 (expressed as MIC $[\mu \mathrm{M}])^{\mathrm{a}}$.

\begin{tabular}{|c|c|c|c|c|c|}
\hline \# & $\mathrm{R}$ & C. albicans & C. tropicalis & MSSA & MRSA \\
\hline $2 \mathrm{k}$ & 4-ClC6H4 & 12.5 & 25.0 & NT & NT \\
\hline 21 & 2-ClC6H4 & NT & NT & 3.0 & 6.0 \\
\hline \multirow[t]{3}{*}{$2 \mathrm{~m}$} & 2,4-C12C6H3 & 6.0 & 12.5 & 2.5 & 5.0 \\
\hline & Imipenem & NT & NT & 1.5 & 2.5 \\
\hline & Itraconazole & 4.4 & 0.2 & NT & NT \\
\hline
\end{tabular}

${ }^{\mathrm{a}} \mathrm{NT}=$ not tested.

atom in the aromatic ring enhanced the potency. In addition to their remarkable antimicrobial activity, the straightforward preparation of allylic thiocyanates from inexpensive and readily available chemicals will allow the full exploitation of this promising class of compounds as future leads for drug development.

\section{Acknowledgments}

The authors wish to thank the Central de Análises (Departamento de Química, UFSC) for spectroscopic analysis. M.F. is grateful to CNPq and CAPES (Brazilian Research Councils) for fellowships. M.M.S. is grateful to CNPq for a research fellowship. E.S.L. is member of the INCT Processos Redox em Biomedicina-Redoxoma (MCT/CNPq). Financial support from INCT-Catalysis (MCT/CNPq) is also gratefully acknowledged.

\section{References}

Allan RD, Dickenson HW, Johnston GAR, Kazlauskas R, Mewett KN (1997) Structural analogues of ZAPA as GABAA agonists. Neurochem Int 30:583-591.

Anesini C, Perez C (1993) Screening of plants used in Argentine folk medicine for antimicrobial activity. J Ethnopharmacol 39:119-128.

Basavaiah D, Reddy BS, Badsara SS (2010) Recent contributions from the Baylis-Hillman reaction to organic chemistry. Chem Rev 110:5447-5674.

Basavaiah D, Veeraraghavaiah G (2012) The Baylis-Hillman reaction: a novel concept for creativity in chemistry. Chem Soc Rev 41:68-78.

Capon RJ, Skene C, Liu EHT, Lacey E, Gill JH, Heiland K, Friedel T (2004) Nematocidal thiocyanatins from a southern Australian marine sponge Oceanapia sp.. J Nat Prod 67:1277-1282.

Chimenti F, Bizzarri B, Bolasco A, Secci D, Chimenti P, Granese A, Carradori S, D'Ascenzio M, Lilli D, Rivanera D (2011) Synthesis and biological evaluation of novel 2,4-disubstituted-1,3-thiazoles as anti-Candida spp. agents. Eur J Med Chem 46:378-382.

Cursino LMC, Santos I, Mariuba LAM, Jeffreys MF, Lima NM, Oliveira JL, Orlandi PP, Nunez CV (2011) Antibacterial activity of Minquartia guianensis extracts and phytochemical evaluation. Emir J Food Agric 23:505-510.

Diekema DJ, Jones RN (2001) Oxazolidinone antibiotics. Lancet 358:1975-1982.
Elhalem E, Bailey BN, Docampo R, Ujváry I, Szajnman SH, Rodriguez JB (2002) Design, synthesis, and biological evaluation of aryloxyethyl thiocyanate derivatives against Trypanosoma cruzi. J Med Chem 45:3984-3999.

Ferreira M, Fernandes L, Sá MM (2009) A highly efficient and general method for the preparation of $(Z)$-allylic bromides derived from Morita-Baylis-Hillman adducts. J Braz Chem Soc 20:564-568.

Foss MH, Eun YJ, Weibel DB (2011) Chemical-biological studies of subcellular organization in bacteria. Biochemistry 50:7719-7734.

Freire CPV, Ferreira SB, de Oliveira NSM, Matsuura ABJ, Gama IL, da Silva FC, de Souza MCBV, Lima ES, Ferreira VF (2010) Synthesis and biological evaluation of substituted $\alpha$ and $\beta$-2,3-dihydrofuran naphthoquinones as potent anticandidal agents. Med Chem Commun 1:1-4.

Iwai N, Fujii T, Nagura H, Wachi M, Kitazume T (2007) Structure-activity relationship study of the bacterial actin-like protein MreB inhibitors: Effects of substitution of benzyl group in $S$-benzylisothiourea. Biosci Biotechnol Biochem 71:246-248.

Kallen AJ, Mu Y, Bulens S, Reingold A, Petit S, Gershman K, Ray SM, Harrison LH, Lynfield R, Dumyati G, Townes JM, Schaffner W, Patel PR, Fridkin SK (2010) Health careassociated invasive MRSA infections, 2005-2008. J Am Med Assoc 304:641-648.

Kohanski MA, Dwyer DJ, Collins JJ (2010) How antibiotics kill bacteria: from targets to networks. Nature Rev 8:423-435.

Lee HH, Collins JJ (2012) Microbial environments confound antibiotic efficacy. Nature Chem Biol 8:6-9.

Liñares GG, Gismondi S, Codesido NO, Moreno SNJ, Docampo R, Rodriguez JB (2007) Fluorine-containing aryloxyethyl thiocyanate derivatives are potent inhibitors of Trypanosoma cruzi and Toxoplasma gondii proliferation. Bioorg Med Chem Lett 17:5068-5071.

Liu J, Yi W, Wan Y, Ma L, Song H (2008) 1-(1-Arylethylidene)thiosemicarbazide derivatives: A new class of tyrosinase inhibitors. Bioorg Med Chem 16:1096-1102.

Mann CM, Markham JL (1998) A new method for determining the minimum inhibitory concentration of essential oils. J Appl Microbiol 84:538-544.

Meier L, Ferreira M, Sá MM (2012) Synthesis of the (E)- $\alpha$ methylalkenoate framework from multifunctionalized allylic phosphonium salts. Heteroatom Chem 23:179-186.

Morell EA, Balkin DM (2010) Methicillin-resistant Staphylococcus aureus: a pervasive pathogen highlights the need for new antimicrobial development. Yale J Biol Med 83:223233. 
Pavan FR, Maia PIS, Leite SRA, Deflon VM, Batista AA, Sato DN, Franzblau SG, Leite CQF (2010) Thiosemicarbazones, semicarbazones, dithiocarbazates and hydrazide/hydrazones: Anti-Mycobacterium tuberculosis activity and cytotoxicity. Eur J Med Chem 45:1898-1905.

Pfaller MA, Chaturvedi V, Espinel-Ingroff A, Ghannoum MA, Gosey LL, Odds FC, Rex JH, Rinaldi MG, Sheehan DJ, Walsh TJ, Warnock DW (2002) Reference method for broth dilution antifungal susceptibility testing of yeasts; approved standard - Second edition. NCCLS - National Committee for Clinical Laboratory Standards (currently Clinical and Laboratory Standards Institute - CLSI), M27-A2, v. 22, nํำ 15, p 1-29.

Pieri FA, Souza CF, Costa JCM, Barrero MAO, Espeschit IF, Silva VO, Moreira MAS (2011) Inhibition of Escherichia coli from mastitic milk by copaiba oil. Semina - Ciências Agrárias 32:1929-1934.

Reck F, Zhou F, Girardot M, Kern G, Eyermann CJ, Hales NJ, Ramsay RR, Gravestock MB (2005) Identification of 4substituted 1,2,3-triazoles as novel oxazolidinone antibacterial agents with reduced activity against monoamine oxidase A. J Med Chem 48:499-506.

Regan BM, Galysh FT, Morris RN (1967) The 2-thiopseudourea moiety, a new local anesthesiophore. J Med Chem 10:649-652.

Sá MM (2003) Allylic azides as potential building blocks for the synthesis of nitrogenated compounds. J Braz Chem Soc 14:1005-1010.

Sá MM, Fernandes L, Ferreira M, Bortoluzzi AJ (2008) Synthesis of allylic thiocyanates and novel 1,3-thiazin-4-ones from 2-(bromomethyl)alkenoates and $S$-nucleophiles in aqueous medium. Tetrahedron Lett 49:1228-1232.

Sá MM, Ferreira M, Bortoluzzi AJ, Fernandes L, Cunha S (2010) Exploring the reaction of multifunctional allylic bromides with $N, S$-dinucleophiles: isothiuronium salts and analogs as useful motifs to assemble the 1,3-thiazine core. Arkivoc (xi):303-321.

Sá MM, Meier L, Fernandes L, Pergher SBC (2007) Acetylation of $\alpha$-methylene- $\beta$-hydroxy esters under heterogeneous catalysis: A regioselective preparation of Baylis-Hillman acetates. Catal Commun 8:1625-1629.

Sá MM, Ramos MD, Fernandes L (2006) Fast and efficient preparation of Baylis-Hillman-derived $(E)$-allylic azides and re- lated compounds in aqueous medium. Tetrahedron 62:11652-11656.

Saeed S, Rashid N, Jones PG, Ali M, Hussain R (2010) Synthesis, characterization and biological evaluation of some thiourea derivatives bearing benzothiazole moiety as potential antimicrobial and anticancer agents. Eur J Med Chem 45:13231331.

Silveira GP, Ferreira M, Fernandes L, Moraski GC, Cho S, Hwang C, Franzblau SG, Sá MM (2012) Allylic thiocyanates as a new class of antitubercular agents. Bioorg Med Chem Lett 22:6486-6489.

Silveira GP, Nome F, Gesser JC, Sá MM, Terenzi H. (2006) Recent achievements to combat bacterial resistance. Quim Nova 29:844-855.

Singh V, Batra S (2008) Advances in the Baylis-Hillman reaction-assisted synthesis of cyclic frameworks. Tetrahedron 64:4511-4574.

Stover CK, Pham XQ, Erwin AL, Mizoguchi SD, Warrener P, Hickey MJ, Brinkman FSL, Hufnagle WO, Kowalik DJ, Lagrou M, Garber RL, Goltry L, Tolentino E, Westbrock-Wadman S, Yuan Y, Brody LL, Coulter SN, Folger KR, Kas A, Larbig K, Lim R, Smith K, Spencer D, Wong GKS, Wu Z, Paulsen IT, Reizer J, Saier MH, Hancock REW, Lory S, Olson MV (2000) Complete genome sequence of Pseudomonas aeruginosa PAO1, an opportunistic pathogen. Nature 406:959-964.

Umamatheswari S, Balaji B, Ramanathan M, Kabilan S (2011) Synthesis, stereochemistry, antimicrobial evaluation and QSAR studies of 2,6-diaryltetrahydropyran-4-one thiosemicarbazones. Eur J Med Chem 46:1415-1424.

Walsh C (2000) Molecular mechanisms that confer antibacterial drug resistance. Nature 406:775-781.

Watts JL, Shryock TR, Apley M, Bade DJ, Brown SD, Gray JT, Heine H, Hunter RP, Mevius DJ, Papich MG, Silley P, Zurenko GE (2008) Performance standards for antimicrobial disk and dilution susceptibility tests for bacteria isolated from animals; approved standard - Third edition. CLSI - Clinical and Laboratory Standards Institute M31-A3, v. 28, no 8, p 1-99.

All the content of the journal, except where otherwise noted, is licensed under a Creative Commons License CC BY-NC. 